Special Section: The economies, ecologies and politics of social forestry in Indonesia Research Article

\title{
Institutional Sustainability of a Community Conservation Agreement in Lore Lindu National Park
}

\author{
Sudirman Daeng Massiri ${ }^{1 *}$, Bramasto Nugroho ${ }^{2}$ Hariadi Kartodihardjo ${ }^{2}$ and Rinekso Soekmadi ${ }^{2}$, \\ ${ }^{1}$ Forestry Faculty, Tadulako University \\ 2 Forestry Faculty, Bogor Agricultural University \\ * Correspondence author: sudi_untad@yahoo.co.id; Tel.: +62-812-2715-3737
}

\begin{abstract}
The arrangement of self-governance institutions is the main obstacle to achieving sustainability for ecosystems and local livelihoods. The aim of this study was to describe the institutional sustainability of Community Conservation Agreement (CCA) in Lore Lindu National Park (LLNP), located in Central Sulawesi Province, Indonesia. This study applied a descriptive method by identifying and analyzing the relationship between characteristics of the community and nearby resources, as well as the regulations and rules (formal and local rules arranged in (CA), behavior and performance of institutional CCA, and the interests and power of stakeholders. The research demonstrates that high institutional sustainability of CCA is not only determined by the relations among the community, but that it is also motivated by the common interests to preserve water in the LLNP area as a means for avoiding disaster. However, principles of collective-choice arrangements, minimal recognition of rights to organize, and nested enterprises in CCA were not running well. Strategies to improve the institutional sustainability of CCA include unifying landscape zones that describe property rights of local communities within a conservation area that is recognized by all stakeholders and should be supported by formal legal rules.
\end{abstract}

Keywords: Conservation; sustainability, local community; Lore Lindu; National Park; collaborative management

\section{Introduction}

Command and control policies for national park management in Indonesia have many obstacles as they often dismiss local resources and the capacity of local institutions. Resource characteristics include features that are important when developing resource management (Cox et al., 2010). Resource characteristics define the interdependent relationships between individuals and groups. These characteristics include incompatibility in use and high exclusion costs (Schmidt, 2004).

High exclusion cost is characteristic of resources system of common pool resources (CPRs) while incompatibility in use is characteristic of resources unit of CPRs (Schmidt, 2004). National park generates goods and services such as biodiversity, landscape beauty and various ecological functions needed by wide people. In addition, it produces timber and non-timber forest products needed by local communities. This characteristic of resources is high exclusion cost. The use of resources for certain purposes creates a situation of incompatibility in use.

High exclusion costs for a local community and incompatibility with resource use are problems common to many national parks in Indonesia. Local communities who lived around national parks have been excluded from utilization of forest resources in national parks. Forests, seen from the local community perspective, is the result of social construction between communities surrounding an ecosystem (Safitri, 2013). However, the local community activities in withdrawing and managing of forest resources are sometimes not in accordance with formal rules of the management of national parks. Livelihood interests and conservation interests can come into conflict within National Park (Yusran et al., 2017). National park designation prohibits certain community activities. Use incompatibility often indicates approximately two or three activities that cannot be implemented concurrently because of specific requirements (Kartodihardjo, 2006). This requires appropriate institutional arrangements to achieve the goal of conservation and ensure community needs are 
met (Acheson, 2006).

The approach that has been applied to overcome high exclusion costs and use incompatibility in LLNP is the Community Conservation Agreement (CCA). This program was initiated by NonGovernment Organizations (NGOs) in the early 2000s (Birner and Mappatoba, 2009). However, implementation of CCA has faced obstacles in terms of its structure and capacity (Massiri, 2015). This requires a new strategy if CCA is to achieve institutional sustainability as a self-governing institution. Self-governing institutions demand autonomy for the proprietors in arranging operational rules (Ostrom 1990).

One critical problem for institutional design is the issue of sustainability (Adiwibowo et al., 2012) and effectiveness to overcome the open access problem. One component of sustainability is sustainable benefit. The success of co-management institutions is determined by the benefits received by local communities (Ray and Bhattacharya, 2011). Communities will be responsible for natural resources when perceived benefits are fast, local, and decent (Uphoff, 1992). Ostrom (1990) defines design principles that lead to long-term management of certain natural resources. These principles include: a clearly defined boundary, congruence, collective-choice arrangements, monitoring, conflict-resolution mechanisms, graduated sanctions, minimal recognition of rights to organize, and nested enterprises that are part of a larger systems.

Institutional performance in the management of natural resources is varied (Ostrom, 1994; Baggio et al. 2016). Some groups design institutions to overcome the open access problem, while others do not (Gautam and Shivakoti, 2005; Quinn et al., 2007; Gavrilets, 2015). Institutional behavior and performance are determined by situation and structure. Situation is characteristic of resources, while structure is the policy or rules that regulated the resource (Schmid 2004). The characteristic of resource systems of LLNP is high exclusion cost for the local community, while the characteristic of unit resources of LLNP is incompatibility in use of resources. Research on institutional sustainability is essential to determine effective institutional arrangements for national park management. The research question of this article is whether the institutional arrangements of CCA is sustained, and whether it becomes a solution to the problem situation of high exclusion costs and incompatibility in use. This research describes: 1) The institutional sustainability of CCA and its effectiveness in sustainably maintaining the LLNP ecosystem; and 2) The strategy for institutional sustainability in achieving a self-governed CCA.

\section{Materials and Methods}

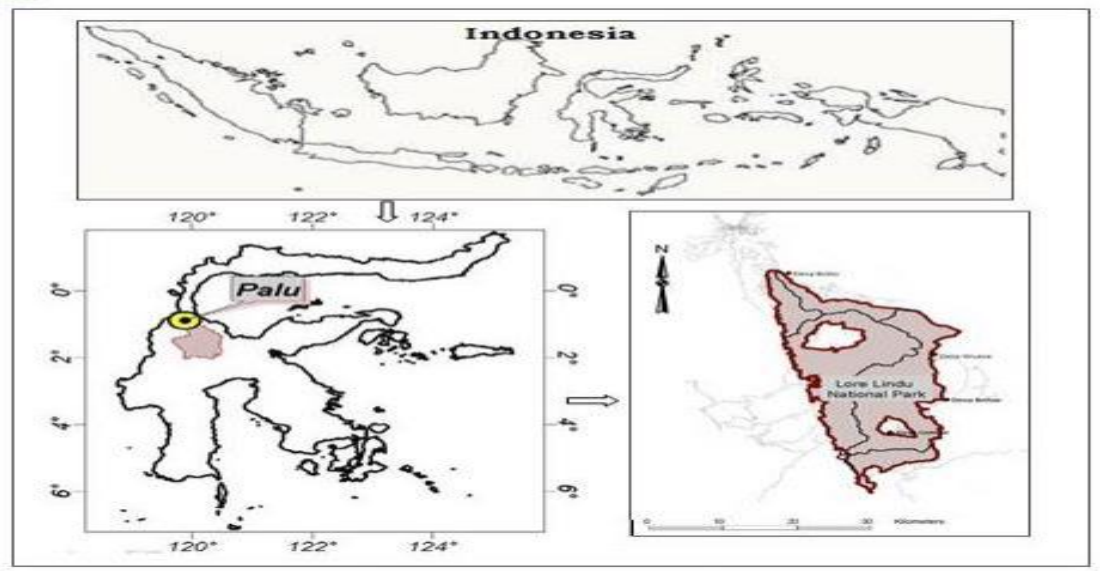

Figure 1. Study area 


\subsection{Study Area}

This research was conducted in Lore Lindu National Park (LLNP), Central Sulawesi Province, Indonesia (Figure 1). There were four locations of CCA evaluation: Bobo, Wuasa, Betue and Lempe villages. These locations were selected based on their community heterogeneity and distance from Palu, the district capital of Central Sulawesi.

\subsection{Data Collection}

Data for this study was collected in 2015 through 1) Focused Group Discussion (FGD) for staff of village conservation council (Lembaga Konservasi Desa/LKD), and communities taking part as a member of the CCA in four villages around the LLNP area in order to obtain data on behavior and performance of the CCA, 2) In-depth interviews for key informants includes village chiefs, leaders of customary institutions, four people from the Buffer Zone Forum (Forum Wilayah Penyangga/FWP), two Local Non-Government Organizations (NGOs) facilitating the arrangement of CCA, and LLNP Officers; 3 ) documentation that detail the rules in the CCA documents and the rules regulating national park management; and 4) making observation plots in the form of two transects of 200 meters in CCA areas.

\subsection{Data Analysis}

This study applied a descriptive method (Irawan, 2006; Neville, 2007), i.e. identifying and classifying the characteristics of study subjects. This study identified and analyzed the relationship between the situation, structure, behavior, performance, interest and power of stakeholders in implementing CCA. Behavior and performance are determined by situation, structure and the roles of stakeholders. Variables of the situation include characteristic of the community and physical characteristics of the forest, while variables of structures include government policy or rules regulated in the protected area, and rules regulated in CCA. Behavior of CCA Institutions was examined with applied design principles from long enduring institutions (Ostrom 1990); while Performance, as outcomes from the institutions, was examined through analysis of forest conditions in the CCA area. Principle and indicators for evaluation of institutional sustainability of CCA are shown in Table 1.

Table 1. Principle and indicator for evaluation of institutional sustainability of CCA

\begin{tabular}{ll}
\hline \multicolumn{1}{c}{ Principles } & \multicolumn{1}{c}{ Indicators } \\
\hline Clearly defined boundary & $\begin{array}{l}\text { clarity of physical boundary of CCA area in LLNP } \\
\text { clarity of property rights and rules of CCA that could be explained by the } \\
\text { community members of CCA } \\
\text { congruence between benefit and cost } \\
\text { congruence between rules and economic conditions of the local community } \\
\text { congruence between rules of CCA and local communities needs } \\
\text { the intensity of meetings in the past five years } \\
\text { the number of people attending the meetings } \\
\text { Collective-choice arrangement }\end{array}$ \\
$\begin{array}{l}\text { Monitoring } \\
\text { Graduated sanctions }\end{array}$ & $\begin{array}{l}\text { customary sanctions could be enforced for the violator } \\
\text { Conflisting institutions and procedures for resolving conflicts that are ongoing } \\
\text { Minimal recognition of rights to }\end{array}$ \\
organize & $\begin{array}{l}\text { LLNP officers recognize the rights of local communities to arrange the internal } \\
\text { use of resources in the CCA area }\end{array}$ \\
Nested enterprises & The linkages of rules at an operational, collective choice, and constitutional level \\
\hline
\end{tabular}

\section{Results and Discussion}

\subsection{Overview of Institutional Sustainability of CCA}

This research examines design principles to assess the institutional sustainability of CCA in LLNP. 


\subsubsection{Clearly defined boundaries}

The clarity of a physical boundary, as well as the clarity of property rights owned by individuals comprise a clearly defined boundary (Quinn et al., 2007). This research used two indicators to describe this principle, namely the clarity of physical boundaries of the CCA area in LLNP, and the clarity of property rights and rules of the CCA that community members were able to explain. This research found that the physical boundaries of the CCA area in LLNP were clearly defined by the communities in Betue village, while the communities in Bobo, Wuasa, and Lempe village could not be defined within the physical boundaries of the CCA area in LLNP.

Communities in Betue and Lempe village understood the arrangement of property rights and rules within the CCA, while in Bobo and Wuasa village many local people did not understand the property rights and rules outlined in the agreement. The size and heterogeneity of the communities within the villages are likely to affect the level of trust and ultimately affect collective action, though their relationship to collective action is typically nonlinear (Poteete and Ostrom 2004). Bobo and Wuasa villages were heterogeneous and included many migrants, while the characteristic of communities in Betue and Lempe village were homogenous with few migrants. The number of villagers in Bobo and Wuasa is, respectively, 1.082 and 3.029, with a total corresponding population density of 47 people/ $\mathrm{km} 2$ and 24 people/ $\mathrm{km} 2$, respectively.

\subsubsection{Congruence}

The principle of congruence is key to arranging CPR institutions. An absence of congruence in local-level management indicates that a community is unable to adapt to changes (Quinn et al. 2007). This research used three indicators of congruence: congruence between benefit and cost, between rules arranged in CCA and the economic condition of the local community, and between rules arranged in CCA and local community needs.

Congruence between benefit and cost is an essential factor in forest management (Agrawal and Yadama 1997). Stakeholder at the local level, including members of LKD, FWP, Village Chief, and customary institution who have the responsibility to control and maintain the rules arranged in the CCA, did not receive appropriate revenue according to their level of effort. Although they did not receive income, some local stakeholders revealed that they received benefits from implementing the CCA rules, such as regulating the availability of water from the forest and in implementing programs for landslide prevention. Maintaining sources of water and avoiding natural disaster caused by forest damage is the motivation of some local institutions for implementing the CCA.

Implementation of the CCA less directly supported the economic improvement of local communities. However, the rules of CCA supported local community needs, particularly needs related to water and landslide prevention. The CCA areas in Bobo and Betue villages are located in a wilderness zone of LLNP; in Lempe village, the CCA area are located in a utilization zone; and in Wuasa village, the CCA area is located in a rehabilitation zone and utilization zone of the LLNP. In the rehabilitation zone, the local communities have a high motivation to cultivate crops. However, formal legal rules of national park management prohibit cultivation in the rehabilitation zone. Based on the formal legal rules of national park management, the designation of the rehabilitation zone is for restoring damaged ecosystems to become close to the original ecosystem conditions.

\subsubsection{Collective-Choice Arrangement}

The third design principle described by Ostrom is the collective-choice arrangement. One of the failures in managing CPRs is that appropriators who depend on the resource are not allowed to participate in modifying the operational rules (Ostrom and Cox 2010). Indicators of collective-choice arrangements in this research include the number of meetings and the number of people attending the meetings. When the local stakeholders were supported by international NGO funding, the 
number of meetings was relatively large. However, the meetings were only attended by the local elite. After funding ceased, meetings were rarely conducted. Stakeholders in Wuasa village have not conducted a meeting to discuss the CCA for five years.

Ting et al. (2012), highlights the principle of collective choice arrangement in community basedco-management of Baishuijiang National Natural Reserve, China, which was not running well because the implementation of community-based collaborative management was still dependent on collaborative projects funded by an international NGO. The same case is true of the village conservation agreement in Kerinci Seblat National Park, Indonesia, in which only $43 \%$ of implementation of the conservation agreement was sustained for five years as part of the Integrated development program (Wood et al., 2014). This situation also seems to be reflected in the case with LLNP, in which the performance of some local institutions implementing the CCA has decreased after the project ends. After project ended, the intensity of the meetings and the number of people attending the meetings were rarely conducted.

\subsubsection{Principle of Monitoring}

Performance is not only determined by collective choice rules, but also how those rules are overseen and enforced (Ostrom and Nagendra, 2006). Institutions can be long enduring if it integrates low cost monitoring approaches (Ostrom, 1990; Andersson et al., 2014). Furthermore, Ostrom (1990) also shows that few resource systems are sustained without conducting active monitoring processes. Regular monitoring demonstrates the ability to improve forest conditions (Gibson et al., 2005; Ostrom and Nagendra, 2006; Pandey, 2010).

Monitoring in accordance with the CCA was conducted by LKD and LLNP Officers, as well as forest rangers, every six months. These monitoring activities continue through efforts of the LKD and LLNP Officers in Bobo, Betue and Lempe villages, but the LKD in Wuasa Village is no longer monitoring the CCA area. The Chief of LKD in Wuasa indicated that LLNP officers were not responding to the LKD, even though LKD members sought to monitor the forest within LLNP. The LKDs in Bobo, Betue and Lempe villages are motivated to monitor forest resources by the need of water from the forest in LLNP, and to avoid natural disasters caused by forest damage.

\subsubsection{Graduated Sanctions}

Imposing sanctions aim to prevent participants from violating the rules (Ostrom and Cox, 2010, Nugroho, 2013). Graduated sanctions must ensure that the cost is greater than the benefit received from breaking the rules (Ostrom 2009).

In the rules of CCA, communities who violate operational rules are subject to customary sanction, determined by customary institutions, community leaders, LLNP officers, and witnessed by the local community. Besides monetary fines, social sanctions carry a social cost because it is witnessed by many people. Customary institutions in Betue and Lempe village still apply the sessions to impose sanctions for violators of operational rules. Customary sanctions imposed on violating parties are called giwu. Customary hearings for violators are carried out openly and witnessed by community members. In Bobo Village, LKD handed over the violator to an authority without conducting a customary trial. In Wuasa, customary sanctions were not enforced, and the violator did not receive sanction. Communities in Bobo and Wuasa village are heterogeneous, with many migrants. Customary sanction therefore, is more difficult to impose due the likelihood that people will adhere to such decisions. Moreover, the land in the rehabilitation zone in Wuasa village was privately owned by local communities. 


\subsubsection{Principle of conflict-resolution mechanisms}

This principle emphasizes the importance of the low cost for conflict resolution in managing the resource system (Ostrom, 1990). In this case, the resolution for resource conflicts is arranged by the local institution according to CCA rules. FWP is an institution that has a responsibility to facilitate conflict resolution related with resources in LLNP and local village use. FWP is the representation of each LKD that is in one sub-district. The establishment of the FWP was facilitated by NGOs through the project entitled Central Sulawesi Integrated Area Development Conservation Program (CSIADCP). This research finds that the capacity of FWP was low after the CSIADCP project ended. However, conflict resolution for the utilization of forest resources in CCA areas in homogenous villages, particularly in Betue and Lempe village, was mediated by customary institutions. Customary rules in homogenous villages are still maintained by the local community, while in heterogeneous villages involve many migrants, and customary rules were no longer obeyed.

\subsubsection{Minimal recognition of rights to organize}

Property rights and rules arranged by the CCA at the operational level facilitated by NGOs are not implemented and enforced by local institutions because LLNP officers did not recognize management rights of the local community to manage the internal use of forest resources in the CCA areas. LLNP officers deny the right of local communities to manage resources within LLNP because some CCA rules are not in line with formal legal rules of LLNP management. According to the LLNP Officer, CCA rules should be reviewed and should refer to formal legal rules at a constitutional level.

In recent years, the government issued a regulation to support community conservation partnership in the protected area, including rules concerning procedures for partnership in the management of the protected area (P85/Menhut-II/2014), as well as technical instructions for conservation partnerships in protected areas (P6/KSDAE/Set/Kum.1/6/2018), which could facilitate better coordination between CCA and LLNP management.

\subsubsection{Recognition of rights to organize}

This research examined the linkages of rules at operational, collective and constitutional levels. It finds that some operational rules and collective choice rules of CCA were not supported by constitutional rules. The rules at the constitutional level are those that determine the form of governance (Carlsson and Berkes, 2005). The governance system of national parks in Indonesia is top-down, governed by the state, and values the uses of resources to emphasize environmental protection. Local CCA decisions cannot be implemented if their decisions were not in line with formal legal rules at the constitutional level. The operational rules of CCA, which are not in line with formal legal rules, are the rules allowing the local community to cultivate crops in the rehabilitation zone and allowing local communities to harvest timber for local needs. However, the designation of utilization zones, based on legal formal rules, is intended to create natural ecotourism and recreation, environmental services, education, research that support development of utilization, cultivation activities, and designation of the rehabilitation zone that intends to support restoration of damaged ecosystems to become more, or close to the natural ecosystem conditions. Development of rules on one level, without supporting rules on other levels, would create an unstable system that is unlikely to endure (Ostrom, 1990).

The high institutional sustainability of CCA was located in Betue and Lempe village, while institutional sustainability of CCA in in Bobo and Wuasa village was moderate to low. In heterogeneous villages (Bobo and Wuasa village), the customary sanctions could not be enforced, and the customary rules regulating the uses of forest resources were no longer understood by local communities. Contrary to homogenous villages with few migrants, customary rules were 
understood by local people, customary sanctions could be enforced, and forest monitoring was still running. However, principles that were functioning poorly in the CCA include collective choice, minimal recognition of the right to organize, and nested enterprises. This indicates that CCA institutions in homogenous villages have not been recognized by the LLNP officers as a part of LLNP management. Condition of Institutional sustainability of CCA is shown in Table 2.

Table 2. Condition of institutional sustainability of CCA

\begin{tabular}{|c|c|c|c|c|}
\hline Prinsip & Indikator & $\begin{array}{l}\text { Institution of } \\
\text { CCA }\end{array}$ & Value & Verifier \\
\hline \multirow{4}{*}{$\begin{array}{l}\text { Clearly defined } \\
\text { boundary }\end{array}$} & \multirow{2}{*}{$\begin{array}{l}\text { clarity of physical boundary of } \\
\text { CCA area in LLNP }\end{array}$} & Betue & 5 & clear \\
\hline & & $\begin{array}{l}\text { Bobo, Wuasa, } \\
\text { Lempe }\end{array}$ & 3 & less clear \\
\hline & \multirow{2}{*}{$\begin{array}{l}\text { clarity of property rights and } \\
\text { rules of CCA that could be } \\
\text { explained by the community } \\
\text { members of CCA }\end{array}$} & Betue, Lempe & 5 & clear \\
\hline & & Bobo, Wuasa & 3 & less clear \\
\hline \multirow[t]{4}{*}{ Congruence } & $\begin{array}{l}\text { congruence between benefit and } \\
\text { cost }\end{array}$ & $\begin{array}{l}\text { Bobo, Wuasa, } \\
\text { Betue, Lempe }\end{array}$ & 3 & less congruence \\
\hline & $\begin{array}{l}\text { congruence between rules and } \\
\text { economic condition of the local } \\
\text { community }\end{array}$ & $\begin{array}{l}\text { Bobo, Wuasa, } \\
\text { Betue, Lempe }\end{array}$ & 3 & $\begin{array}{l}\text { less support for the improvement of } \\
\text { the local community economies }\end{array}$ \\
\hline & \multirow[t]{2}{*}{$\begin{array}{l}\text { congruence between rules CCA } \\
\text { and the local communities needs }\end{array}$} & $\begin{array}{l}\text { Bobo, Betue, } \\
\text { Lempe }\end{array}$ & 5 & congruence \\
\hline & & Wuasa & 3 & less congruence \\
\hline \multirow{4}{*}{$\begin{array}{l}\text { Collective- } \\
\text { choice } \\
\text { arrangement }\end{array}$} & \multirow[t]{2}{*}{$\begin{array}{l}\text { the intensity of meeting in the } \\
\text { past five years }\end{array}$} & $\begin{array}{l}\text { Bobo, Betue, } \\
\text { Lempe }\end{array}$ & 3 & seldom \\
\hline & & Wuasa & 1 & never \\
\hline & \multirow[t]{2}{*}{$\begin{array}{l}\text { the number of people attending } \\
\text { the meetings }\end{array}$} & Betue, Lempe & 3 & $\begin{array}{l}\text { not many local communities } \\
\text { participating }\end{array}$ \\
\hline & & Bobo, Wuasa & 1 & $\begin{array}{l}\text { most local communities did not } \\
\text { participate }\end{array}$ \\
\hline \multirow[t]{2}{*}{ Monitoring } & \multirow[t]{2}{*}{$\begin{array}{l}\text { monitoring processes are actively } \\
\text { conducted by the local institution }\end{array}$} & $\begin{array}{l}\text { Bobo, Betue, } \\
\text { Lempe }\end{array}$ & 5 & active \\
\hline & & Wuasa & 1 & did not active \\
\hline \multirow{3}{*}{$\begin{array}{l}\text { Graduated } \\
\text { sanctions }\end{array}$} & \multirow{3}{*}{$\begin{array}{l}\text { customary sanction could be } \\
\text { enforced for the violator }\end{array}$} & Betue, Lempe & 5 & could be enforced \\
\hline & & Bobo & 3 & $\begin{array}{l}\text { could not be enforced, but local } \\
\text { institution handed over the violator } \\
\text { to the appropriate authority }\end{array}$ \\
\hline & & Wuasa & 1 & $\begin{array}{l}\text { could not be enforced, the violator } \\
\text { did not impose the sanction }\end{array}$ \\
\hline \multirow{2}{*}{$\begin{array}{l}\text { Conflict } \\
\text { resolution } \\
\text { mechanism }\end{array}$} & \multirow{2}{*}{$\begin{array}{l}\text { existing institutions and } \\
\text { procedures for resolving conflicts } \\
\text { that are still running }\end{array}$} & Betue, Lempe & 5 & $\begin{array}{l}\text { there were active institutions and } \\
\text { procedures for resolving conflicts }\end{array}$ \\
\hline & & Bobo, Wuasa & 3 & $\begin{array}{l}\text { there were institutions and } \\
\text { procedures for resolving conflict, but } \\
\text { it was no longer operational }\end{array}$ \\
\hline $\begin{array}{l}\text { Minimal } \\
\text { recognition of } \\
\text { rights to } \\
\text { organize } \\
\end{array}$ & $\begin{array}{l}\text { LLNP officer recognized the rights } \\
\text { of local community to arrange } \\
\text { the internal use of resources in } \\
\text { CCA area }\end{array}$ & $\begin{array}{l}\text { Bobo, Wuasa, } \\
\text { Betue, Lempe }\end{array}$ & 3 & was not recognized by LLNP officer \\
\hline $\begin{array}{l}\text { Nested } \\
\text { enterprises }\end{array}$ & $\begin{array}{l}\text { The linkages of rules at an } \\
\text { operational, collective choice, } \\
\text { and constitutional level }\end{array}$ & $\begin{array}{l}\text { Bobo, Wuasa, } \\
\text { Betue, Lempe }\end{array}$ & 3 & $\begin{array}{l}\text { some operational rules and } \\
\text { collective-choice rules of CCA were } \\
\text { unsupported by constitutional rules } \\
\text { of national park management }\end{array}$ \\
\hline
\end{tabular}

\subsection{The Effectiveness of CCA institutions}

Forest ecosystem conditions in the CCA area represent the institutional performance of CCA. Forest ecosystem conditions include forest encroachment, composition of vegetation, and basal area of tree 
stands. Before implementing the CCA, forest encroachment in Bobo and Wuasa Village was common, while the forest encroachment in Betue and Lempe village was low. Since implementing the institution of CCA, forest encroachment activities in Bobo, Betue and Lempe villages has decreased. In contrast, forest encroachment in Wuasa village continues to occur, and within the Wuasa village, monitoring and graduated sanctions are implemented by local institutions. CCA areas with comparatively better forest conditions still implement the principle of monitoring and graduated sanctions. Forest conditions within the study villages are included in Table 1.

Table 3. Forest ecosystem condition in CCA area

\begin{tabular}{|c|c|c|c|c|}
\hline \multirow{2}{*}{ Indicator of forest ecosystem } & \multicolumn{4}{|c|}{ Forest condition in CCA area } \\
\hline & Bobo village & Wuasa village & Betue village & Lempe village \\
\hline \multicolumn{5}{|l|}{$\begin{array}{l}\text { Composition of vegetation } \\
\text { (N/ha) }\end{array}$} \\
\hline - Seedling & 12,250 & 6,250 & 7,750 & 17,000 \\
\hline - Sapling & 1,800 & 1,480 & 2,160 & 1,920 \\
\hline - Pole & 210 & 200 & 280 & 265 \\
\hline - Tree & 198 & 175 & 163 & 188 \\
\hline Basal area of stand ( $\left.\mathrm{m}^{2} / \mathrm{ha}\right)$ & 37.33 & 25.24 & 29.55 & 25.31 \\
\hline Forest encroachment & $\begin{array}{l}\text { Have not } \\
\text { occurred }\end{array}$ & occur & $\begin{array}{l}\text { Have not } \\
\text { occurred }\end{array}$ & $\begin{array}{l}\text { Have not } \\
\text { occurred }\end{array}$ \\
\hline $\begin{array}{l}\text { Institutional sustainability of } \\
\text { CCA }\end{array}$ & Moderate & low & high & high \\
\hline \multicolumn{5}{|l|}{$\begin{array}{l}\text { Physical characteristic of } \\
\text { forest }\end{array}$} \\
\hline $\begin{array}{l}\text { - Distance from the } \\
\text { settlement }\end{array}$ & $0.3 \mathrm{~km}$ & $0.6 \mathrm{~km}$ & $1.5 \mathrm{~km}$ & $0.4 \mathrm{~km}$ \\
\hline - $\quad$ Slope (\%) & $>60 \%$ & $0-8 \%$ & $40-60 \%$ & $26-40 \%$ \\
\hline - $\quad$ Altitude & $750 \mathrm{msl}$ & $1,150 \mathrm{msl}$ & $1,041 \mathrm{msl}$ & $1,227 \mathrm{msl}$ \\
\hline \multicolumn{5}{|l|}{ Characteristic of community } \\
\hline - $\quad$ Ethnic diversity & Heterogeneous & Heterogeneous & Homogeneous & Homogeneous \\
\hline - Indigenous people & Kaili & $\mathrm{Napu}$ & Rampi & Behoa \\
\hline
\end{tabular}

Local institutions influence forest conditions (Agrawal and Yadama, 1997), but in this case, the number of trees and the basal area of the stands did not have a linear relationship with the institutions. The basal area of stands are not directly determined by the institution, but by the physical characteristics and socioeconomic conditions (Tucker et al., 2007). However, the robustness of an institution has an important role in preventing forest encroachment. CCA institutions that have high sustainability are able to prevent forest encroachment.

The highest average basal area was located in the Bobo village CCA area, and the lowest average basal areas were located in Wuasa and Lempe village CCA areas. In this case, the basal area of stands were determined by the physical characteristics, particularly by the slope. The local community preference not 
to use steeply sloped forests in Bobo was based on their desire to protect sources of water and avoid landslides. The local communities in Bobo village were highly dependent on the water from LLNP area. However, local communities in Wuasa and Lempe village preferred to use the forest that has a relatively flat slope to farm and to take the timber for local needs. In Lempe village, local institutions were conducting forest monitoring and graduated sanctions so that forest encroachment could be prevented, while in Wuasa village, the local institution was not conducting forest monitoring and graduation sanctions so that forest encroachment occurred.

\subsection{Policy Space for Self-Governing Institutions of CCA}

From an institutional perspective, policy reform is contingent on the arrangement of property rights for LLNP resources that consider a given situation and the capacity of stakeholders. The policy space for achieving self-governing institutions through the CCA includes: 1) The arrangement of community conservation area that is recognized by all stakeholders; and, 2) The arrangement of property rights and authority in the collective decision-making process.

\subsubsection{Rearrangement of the area of CCA}

The clear delineation of area as seen as legitimate by all stakeholders is a principal requirement in achieving sustainable forest management (Sinabutar et al., 2014; Kartodihardjo, 2016). Recognition of forest areas are possible if the designation process ensures realization of a spatial arrangement agreed upon by all stakeholders. Spatial arrangement within LLNP should clarify all local community rights in the CCA area.

There are approximately 31 villages adjacent to LLNP that implemented a CCA facilitated by NGOs. The map of CCA areas contained in CCA documentation is not an appropriate basis for management because the CCA area outlined in the map has not been agreed upon by the communities or the LLNP officers. Differences in understanding between local communities and LLNP officers about the CCA area confirm that the CCA areas have not had accountability and legitimacy. Therefore, LLNP officers and local communities should renegotiate and determine clear CCA area boundaries. Furthermore, the community conservation management areas need to be specified within CCA area maps and integrated into the management planning of LLNP.

Requirements that should be considered in allocating CCA areas include; 1) The local community dependency on resources in that area; 2) The CCA area should not be managed and controlled by the local institutions. This means that local institutions must have a high capacity to control and manage the uses of natural resources in a CCA area, and that the management activities of local communities must be supported by the broader goals of conservation. The arrangement of CCA areas should be integrated into the LLNP zoning area, so that it can be enforced through nested accountability mechanisms. Integration, in this case, is to explore and adopt traditional spatial planning knowledge for local communities within the LLNP zoning map

\subsubsection{Rearrangement of property rights and authority in collective decision-making processes}

The concept of sustainability related to collective action rests on the emphasis on the collective decision-making processes (Anderies et al., 2013). Implementation of collective-choice rules in regulating the uses of resources in LLNP is a critical point for realizing CCA as a self-governing institution. The strong autonomy of rule-making at the local level is a key predictor of better forest management that supports local livelihoods (Singh et al. 2011). Based on property rights theory (Schlager and Ostrom, 1992), the institutional sustainability of CCA could be realized if local community rights at a collective choice level were recognized and enforced by the government, and ultimately the institution of CCA should be a part of the LLNP management and collaboration system. Rights at a collective-choice level include management rights, exclusion rights and 
alienation rights (Schlager and Ostrom, 1992).

Based on canonical design principles (Ostrom, 1990), three principles of institutional sustainability failed to assist communities in forest management. These principles were collectivechoice arrangements, recognition of the right to organize, and nested enterprises. These principles are related to autonomy in the decision-making process. The ineffectiveness of the principles was caused partly by structural barriers of legal and formal rules. The legal and formal rules of national park management have not yet explicitly granted the collective-choice rights of local communities in managing resources in the national park. Institutional sustainability of the CCA requires legal protection that recognizes local community rights to manage protected areas, thus incorporating the principle of nested authority.

There are at least three requirements for promoting CCA management as a self-governing institution. These requirements are the basis for assessing whether the local community deserves to have the rights at the collective level to regulate the uses of forest resources in LLNP area. These requirements include: First, local dependency on forest resources to meet livelihood needs. The proprietor of the resources who depends on resources has a high incentive to maintain those resources (Agrawal and Ostrom ,2001). Second, local communities have a common interest in forest resources. The common interest of the local communities to preserve water sources in the forest in the LLNP area is the driving force of the collective action within communities that preserve forest resources. Third, local communities must have strong social capital. Social capital consists of norms, relations, and trust (Putnam, 2001; Nurrochmat et al., 2016). Strong social capital of local communities promotes cooperation and lower transaction costs (Ray and Bhattacharya, 2011; Roslinda, 2013).

\section{Conclusions}

The institution of CCA arrangements have been negotiated since the early 2000s but have not yet become part of the institution of National Park management. CCA institutions have barriers to endure over the long-term. Specifically, these barriers include insufficient principles related to collective-choice arrangements, the lack of recognition of rights to organize, and nested enterprises and authority. Therefore, recognizing, strengthening, and integrating CCA institutions within the framework of LLNP management should be conducted by LLNP officers to promote sustainable selfgovernance within local communities. The institutional sustainability of CCAs should must promote unified landscape zoning that clarifies property rights of local communities in the community conservation area, and which is thereafter recognized by all stakeholders.

Author Contributions: Bramasto Nugroho, Hariadi Kartodihardjo, and Rinekso Soekmadi designed the concept of research and analyzed the data; Sudirman Daeng Massiri designed the research, performed the research, analyzed the data, and led the paper writing effort.

Conflicts of Interest: We declare that there is no conflict interest of our research. "The founding sponsors had no role in the design of the study; in the collection, analyses, or interpretation of data; in the writing of the manuscript, and in the decision to publish the results".

\section{Acknowledgments}

The authors extend their acknowledgment to the Ministry of Research, Technology and Higher Education of the Republic of Indonesia for the scholarship support to budgeting for, and accomplishing this research. Sincere appreciation is also extended to anonymous reviewers for correction and comments.

\section{References}

Acheson, J. M. (2006). Institutional failure in resource management. Annu. Rev. Anthropol., 35, 117134.doi: https://doi.org/10.1146/annurev.anthro.35.081705.123238 
Adiwibowo, S., Shohibuddin, and Kartodihardjo, H. (2012). Kontestasi Devolusi: Ekologi Politik Pengelolaan Hutan Berbasis Masyarakat. In "Kembali Ke Jalan Lurus. Kritik Penggunaan IImu dan Praktek Kehutanan Indonesia" (H. Kartodihardjo, ed.). Forci Development, Bogor.

Agrawal, A., \& Ostrom, E. (2001). Collective action, property rights, and decentralization in resource use in India and Nepal. Politics \& Society, 29(4), 485-514. doi: http://dx.doi.org/10.1177/0032329201029004002

Agrawal, A., \& Yadama, G. (1997). How do local institutions mediate market and population pressures on resources? Forest Panchayats in Kumaon, India. Development and change, 28(3), 435-465. doi: https://doi.org/10.1111/1467-7660.00050

Anderies, J. M., Folke, C., Walker, B., and Ostrom, E. (2013). Aligning key concepts for global change policy: robustness, resilience, and sustainability. Ecology and society (18)8. https://doi.org/10.5751/ES-05178-180208

Andersson, K., Benavides, J. P., \& León, R. (2014). Institutional diversity and local forest governance. Environmental Science \& Policy, 36, 61-72. doi:http://dx.doi.org/10.1016/j.envsci.2013.07.009

Baggio, J. A., Barnett, A. J., Perez-lbara, I., Brady, U., Ratajczyk, E., Rollins, N., ... \& Anderies, J. M. (2016). Explaining success and failure in the commons: the configural nature of Ostrom's institutional design principles. International Journal of the Commons, 10(2), 417-439.doi: http://doi.org/10.18352/ijc.634

Birner, R., and Mappatoba, M. (2009). Co-management of protected areas: A case study from Central Sulawesi, Indonesia. In "Conserving and Valuing Ecosystem Services and Biodiversity: Economic, Institutional and Social Challenges" (K. Ninan, ed.). Francis and Tailor, United Kingdom.

Carlsson, L., \& Berkes, F. (2005). Co-management: concepts and methodological implications. Journal of environmental management, 75(1), 6576.doi:http://dx.doi.org/10.1016/j.jenvman.2004.11.008

Cox, M., Arnold, G., and Tomás, S. V. (2010). A review of design principles for community-based natural resource management. Ecology and Society, 15, (4). http://www.ecologyandsociety.org/vol15/iss4/art38/

Gautam, A. P., \& Shivakoti, G. P. (2005). Conditions for successful local collective action in forestry: some evidence from the hills of Nepal. Society and Natural Resources, 18(2), 153-171. doi:http://dx.doi.org/10.1080/08941920590894534

Gavrilets, S. (2015). Collective action problem in heterogeneous groups. Philosophical Transactions of the Royal Society B: Biological Sciences (370), 20150016. doi:http://dx.doi.org/10.1098/rstb.2015.0016.

Gibson, C. C., Williams, J. T., and Ostrom, E. (2005). Local enforcement and better forests. World Development, 33, 273-284.doi: http://dx.doi.org/10.1016/j.worlddev.2004.07.013

Irawan, P. (2006). "Penelitian Kualitatif dan Kuantitatif untuk IImu-IImu sosiall," DIA FISIP UI, Jakarta. Kartodihardjo, H. (2006). Ekonomi dan Institusi Pengelolaan Hutan. Institute for Development Economics of Agronomic and Rural Areas, Bogor.

Kartodihardjo, H. (2016). Diskursus dan Kebijakan Institusi-Politik Kawasan Hutan: Menelusuri Studi Kebijakan dan Gerakan Sosial Sumberdaya Alam di Indonesia. In "Orasi IImiah Guru Besar IPB". Institut Pertanian Bogor, Bogor.

Massiri, S. D. (2015). Institutional Sustainability Barriers of Community Conservation Agreement as a Collaboration Management in Lore Lindu National Park. Jurnal Manajemen Hutan Tropika Jurnal Manajemen Hutan Tropika, 21(3), 147-154. doi: http://dx.doi.org/10.7226/jtfm.21.3.147

Neville, C. (2007). "Introduction to research and research methods," University of Bradford, United Kongdom.

Nugroho, B. (2013). Reformasi kelembagaan dan tata pemerintahan. Faktor pemungkin menuju tata 
kelola kehutanan yang baik. In "Kembali Ke Jalan Lurus. Kritik Penggunaan IImu dan Praktek Kehutanan Indonesia" (H. Kartodihardjo, ed.). Forcy Development, Bogor.

Nurrochmat, D. R., Darusman, D., and Ekawati, M. (2016). "Kebijakan Pembangunan Kehutanan dan Lingkungan," IPB Press, Bogor.

Ostrom, E. (1990). "Governing the Common," Cambidge University Press, New York.

Ostrom, E., Gardner, R., Walker, J., and Walker, J. (1994). "Rules, games, and common-pool resources," University of Michigan Press.

Ostrom, E. (2009). Design principles of robust property-rights institutions: what have we learned? Property Rights and Land Policies, K. Gregory Ingram, Yu-Hung Hong, eds., Cambridge, MA: Lincoln Institute of Land Policy.

Ostrom, E., \& Cox, M. (2010). Moving beyond panaceas: a multi-tiered diagnostic approach for social-ecological analysis. Environmental conservation, 37(4), 451-463. doi: http://dx.doi.org/10.1017/S037689291000083 .

Ostrom, E., and Nagendra, H. (2006). Insights on linking forests, trees, and people from the air, on the ground, and in the laboratory. Proceedings of the national Academy of sciences, 103, 19224-19231. https://doi.org/10.1073/pnas.0607962103.

Pandey, D. N. (2010). Critical necessity of local monitoring and enforcement for sustainable governance of forests. Indian Forester, 136, 1155-1163.

Poteete, A. R., and Ostrom, E. (2004). Heterogeneity, group size and collective action: The role of institutions in forest management. Development and change, 35, 435-461. doi: https://doi.org/10.1111/j.1467-7660.2004.00360.x

Putnam, R. (2001). Social capital: Measurement and consequences. Canadian Journal of Policy Research, 2, 41-51.

Quinn, C. H., Huby, M., Kiwasila, H., and Lovett, J. C. (2007). Design principles and common pool resource management: An institutional approach to evaluating community management in semi-arid Tanzania. Journal of Environmental Management, 84, 100-113. doi: https://doi.org/10.1016/j.jenvman.2006.05.008

Ray, B., and Bhattacharya, R. N. (2011). Transaction costs, collective action and survival of heterogeneous co-management institutions: case study of forest management organisations in West Bengal, India. The Journal of Development Studies, 47, 253-273. doi: https://doi.org/10.1080/00220381003706692

Roslinda, E. (2013). Pilihan Kebijakan Pengelolaan Taman Nasional Danau Sentarum Provinsi Kalimantan Barat. Disertasi, Institut Pertanian Bogor, Bogor.

Safitri, M. A. (2013). Keniscayaan Transdisiplinaritas dalam Studi Sosio-Legal terhadap Hutan Hukum dan Masyarakat. In "Kembali Ke Jalan Lurus. Kritik Penggunaan IImu dan Praktek Kehutanan Indonesia" (H. Kartodihardjo, ed.). Nailil Printika, Yogyarakarta.

Schlager, E., and Ostrom, E. (1992). Property-rights regimes and natural resources: a conceptual analysis. Land economics, 249-262.doi: https://doi.org/10.2307/3146375

Schmid, A. A. (2004). "Conflict and Coorperation; Institutional and Behavioral Economics," Blackwell Publishing, United Kingdom.

Sinabutar, P., Nugroho, B., Kartodihardjo, H., and Darusman, D. (2014). Reforming the gazettment of state forest area in Riau Province. Jurnal Manajemen Hutan Tropika, 20, 179-186. doi https://doi.org/10.7226/jtfm.20.3.179

Singh, V. S., Pandey, D. N., and Prakash, N. P. (2011). What determines the success of joint forest management? Science-based lessons on sustainable governance of forests in India. Resources, Conservation and Recycling, 56, 126-133. doi: https://doi.org/10.1016/j.resconrec.2011.09.015

Ting, Z., Shivakoti, G. P., Haiyun, C., and Maddox, D. (2012). A survey-based evaluation of community-based co-management of forest resources: a case study of Baishuijiang National Natural Reserve in China. Environment, development and sustainability, 14, 197-220. doi: 
http://dx.doi.org/10.1007/s10668-011-9323-7

Tucker, C. M., J. C. Randolph, and E. J. Castellanos. 2007. "Institutions, Biophysical Factors and History: An Integrative Analysis of Private and Common Property Forests in Guatemala and Honduras." Human Ecology, 35(3):259-74.doi: http://dx.doi.org/10.1007/s10745-006-90870

Uphoff, N. T. (1992). "Local institutions and participation for sustainable development," Sustainable Agriculture Programme of the International Institute for Environment and Development London.

Wood, P., Sheil, D., Syaf, R., and Warta, Z. (2014). The Implementation and Sustainability of Village Conservation Agreements Around Kerinci Seblat National Park, Indonesia. Society \& Natural Resources, 27, 602-620. doi:https://doi.org/10.1080/08941920.2014.901464

Yusran, Y., Sahide, M. A. K., Supratman, S., Sabar, A., Krott, M., and Giessen, L. (2017). The empirical visibility of land use conflicts: From latent to manifest conflict through law enforcement in a national park in Indonesia. Land Use Policy, 62, 302-315. doi: https://doi.org/10.1016/j.landusepol.2016.12.033 